\title{
Seventh Graders' Needs Analysis towards EFL Subject
}

\author{
Ghea Kyat Priyanka, Dewi Nur Asyiah, and Novia Tri Febriani \\ Indonesia University of Education \\ gheakyatpriyanka@gmail.com
}

\begin{abstract}
This study was motivated by data revealing that decision making upon learning objectives were taken merely from curriculum and syllabus review, while students' preferences towards their needs in learning was neglected. Therefore, this study is aimed to find out students' needs in studying English as a foreign language. Questionnaire and semi standardized interview under qualitative approach were administered to 32 seventh graders and 2 English teachers. The findings came up that students' motive in learning English was mainly to travel abroad. Furthermore, they perceived that their listening and writing skills were lower than the other skills. They also found difficulties in learning due to the unpleasant facilitation. In addition, they preferred to learn English in group. This study is expected to give more preferences to teachers in deciding upon what skills should be emphasized and what learning styles and teaching methods will better be applied in teaching and learning.
\end{abstract}

Keywords: needs analysis, seventh graders, EFL subject

\section{INTRODUCTION}

It has been proposed and proved by many experts that needs analysis is fundamental and significant to course design and teaching (Hutchinson and Waters, 1987; Brown, 1995; Carter \& Nunan, 2001; Richards, 2001; Nation and Macalister, 2010). Due to its significances, needs analysis should be conducted before deciding lesson objectives, whether it is in a big scope such as in a curriculum or in a small scope like in a syllabus or a lesson plan. As it is stated by Brown (1995), needs analysis serves as the basis for developing a curriculum that will meet the learning needs of a particular group of students. However, despite its importance in setting up learnersadjust objectives, needs analysis is still being ignored and neglected by some teachers.

A preliminary research was conducted on March 26, 2016 in one of public Junior High Schools in Cirebon based on the aforementioned issue. From the interview with two English teachers, it was revealed that decision making on lesson objectives was taken merely from the review of the curriculum and syllabus. Meanwhile, students' perspectives toward their own needs were not taken into consideration. Head of curriculum affair admitted that a needs analysis indeed had never been conducted in the school due to limitation of time and financial resources as well as lack of experience in conducting such analysis.

This fact is unfortunate since needs analysis should have been used as a compass in determining lesson objectives (Hutchinson \& Waters, 1987). Moreover, it is proposed by Watanabe (2006) that without taking students' view towards their own needs, curriculum and program improvement cannot continue well. Therefore, due to the existing revealed issue in the field and by considering the significance of needs analysis, this study is aimed to find out students' needs in studying English as a foreign language.

Needs, as defined by Richards (2001, p. 54), are described in terms of a linguistic deficiency. He decribed needs as "the differences between what a student can presently do in a language and what he should be able to do". Dealing with needs analysis, Songhori (2008) proposed that needs analysis has a vital role in the process of designing and carrying out any language course. It is the first step in course design and it provides validity and relevancy for all subsequent course design activities (Johns, 1991 in Songhori, 2008). Without conducting well needs analysis, there is a huge possibility that the curriculum will fail its objectives. Therefore, it seems reasonable to argue that needs analysis plays a major role in curriculum development. However, it is necessary to bear in mind that needs are not static, but rather changeable (Soruc, 2012). Due to that case, curriculum developers should view curriculum development as a cyclical process without an end. Thus, there is an absolute need to gather as much information as possible towards students' needs continuously. The procedures used to collect information about students' needs are defined as needs analysis (Richards, 2001). Furthermore, Nation and Macalister (2010, p. 24) add, "needs analysis makes sure that the course will contain relevant and useful things to learn".

Richards (2001, p. 52) believes that the very first step to do in conducting a need analysis is to decide exactly what its purpose is or purposes are. His argument is supported by Lowe (2009) who says that the starting point in conducting needs analysis is questioning why the analysis is being done. Needs analysis in language teaching, as cited in Richards (2001, p. 52), may be used for a number of different purposes. For instance, it is used to find out what language skills a student needs in order to perform a particular role, to help determine if an existing course addresses the needs of potential students, to identify a change of direction that people in a reference group feel is important, etc. Any purpose or purposes determined by curriculum planners will influence the time needs analysis is conducted. According to Richards (2001, p. 54), "needs analysis may take time prior to, during, or after a language 
program." For example, if the analysis is aimed to find out what language skills a student needs in order to perform a particular role, then the needs analysis will better be conducted in the beginning of a language program. If needs analysis is purposefully done as a curriculum review, it can be conducted during or after a language program (Martin, 2005).

Based on the above data showing significances of conducting needs analysis, this present study is conducted by focusing the attention to the following research questions:

1. What are seventh graders' perspectives of English for their future life?

2. What are seventh graders' perspectives of their language skills and knowledge in learning English?

3. What difficulties do seventh graders face in learning English as a foreign language?

4. What are seventh graders' perspectives toward favorable learning styles and teaching methods in learning English?

5. What are seventh graders' suggestions in terms of the better strategies for learning English as a foreign language?

\section{METHODS}

The current study attempts to reveal the needs of the seventh graders in learning English as a foreign language. Therefore, the investigation was conducted under qualitative design in which it presents a natural and 'holistic' picture of the phenomena being studied (Malik \& Hamied, 2016, p. 177).

The participants of this study were 32 seventh graders in one of public Junior High Schools in Cirebon and 2 EFL teachers of seventh grade. The participants were chosen purposively based on certain criteria (Berg, 2001, p. 32). Firstly, the needs analysis had never been conducted in that school. Therefore, this study was expected to give meaningful information for curriculum development in the school. Secondly, in Indonesia context, seventh grade is the level where English is generally taught as a foreign language. Thus, gathering specific information concerning students' needs as earlier as possible was expected to support the improvement in their learning. Moreover, the data in this study were collected through questionnaire and interview. Both questionnaire items and interview questions for the students were translated from English into Bahasa to ease them in giving the responds. For the questionnaire, it was adapted from the research of AlHamlan and Baniabdelrahman (2015) which was divided into five sections. The total items of 74 statements in the sections were to be answered by the students using Likert scale with 'strongly agree', 'agree', 'not sure', 'disagree', and 'strongly disagree' rating of assessment. In addition, to provide in-depth information regarding the students' needs, a semi-standardized interview was conducted to 6 students, which were selected randomly. Meanwhile, 4 interview questions for the teachers were self-developed in order to give additional information towards students' needs.

In analyzing the data, a mix-method was applied in the study. Fraenkel et al. (2012) propose that the use of mixmethod provides a more complete understanding of research problems than does the use of either approach alone. In this point, the data gained from the questionnaire were analyzed quantitatively to get the means of each section. Each respond in the Likert scale was valued. All of the students' answers were listed and then the means of each section were calculated to get the rank of the items that students mostly concerned with as their needs. After that, the data were described and interpreted in order to answer the research questions. Furthermore, the data gained from questionnaire would be compared with the data from the interview.

\section{RESULTS AND DISCUSSION}

A five-section questionnaire was distributed to 32 seventh graders aiming to reveal their needs in learning English in EFL context. The data from which the highest mean of each section in the questionnaire can be seen is presented in the following table.

Table 1. Students' Perspectives towards Needs in Learning English

\begin{tabular}{|c|c|c|c|}
\hline Section & Topic & Statement & Mean \\
\hline 1 & $\begin{array}{l}\text { English for } \\
\text { future life }\end{array}$ & $\begin{array}{l}\text { English learning } \\
\text { helps me in traveling } \\
\text { abroad and to feel } \\
\text { confident }\end{array}$ & 4.31 \\
\hline \multirow[b]{3}{*}{2} & $\begin{array}{l}\text { - Language } \\
\text { skills }\end{array}$ & $\begin{array}{l}\text { Feeling confident } \\
\text { with vocabulary }\end{array}$ & 3.55 \\
\hline & $\begin{array}{l}\text { - Linguistic } \\
\text { needs }\end{array}$ & $\begin{array}{l}\text { To pronounce words } \\
\text { in English correctly }\end{array}$ & 4.66 \\
\hline & $\begin{array}{l}\text { - Curricular } \\
\text { and } \\
\text { Extracurricul } \\
\text { ar activities }\end{array}$ & $\begin{array}{l}\text { I prefer to learn } \\
\text { English from the } \\
\text { activities } \\
\text { resemble the daily } \\
\text { life situations }\end{array}$ & 3.69 \\
\hline 3 & $\begin{array}{l}\text { Difficulties in } \\
\text { learning } \\
\text { English }\end{array}$ & $\begin{array}{l}\text { The language } \\
\text { learning is not } \\
\text { facilitated well in the } \\
\text { class }\end{array}$ & 3.06 \\
\hline 4 & $\begin{array}{l}\text { - Favourable } \\
\text { learning } \\
\text { styles }\end{array}$ & $\begin{array}{l}\text { I prefer to perform } \\
\text { the activities in big } \\
\text { groups under the } \\
\text { teacher's supervision }\end{array}$ & 4.31 \\
\hline & $\begin{array}{l}\text { - Favourable } \\
\text { teaching } \\
\text { method }\end{array}$ & $\begin{array}{l}\text { I need the teacher to } \\
\text { translate the difficult } \\
\text { words for me }\end{array}$ & 4.53 \\
\hline 5 & $\begin{array}{l}\text { Suggestions in } \\
\text { learning } \\
\text { English }\end{array}$ & $\begin{array}{l}\text { I wish to learn more } \\
\text { new words in } \\
\text { different fields }\end{array}$ & 4.19 \\
\hline
\end{tabular}


Section 1 was highly related to students' motivation in learning English. Motivation as defined by Dornyei (2005) is a reason why people decide to do something which in turn will determine their efforts and their sustainability of doing what they have decided. From the data gathered, it was revealed that the students learned English for various purposes. Among 11 items in this section, 3 main purposes mostly chosen by the students cover: to travel abroad, to help them feel confident, and to help them fluent in speaking English. They agreed that learning English can facilitate them in achieving those purposes. The result above is also supported by findings from the interview showing that most students learn English so as to speak English fluently by which they can go overseas confidently. Having the same sound, Watanabe (2006) in his study also found out that most students were highly motivated by their perceptions that, in EFL context, the biggest advantage of learning English for students is in facilitating them to go abroad, whether it is for the purpose of travelling, working, or studying. The result in this section can be considered significant to be taken into account by English teachers or practitioners as students' motivation in learning needs to be concerned so as to create an effective teaching. By knowing what motivates their students the most, teachers can take benefit in determining and selecting materials to be taught, activities to be conducted, and tasks to be given to the students. In fact, Kaboody (2013) proposed that teachers play a vital role in decreasing or increasing students' motivation.

Section 2 was aimed at finding out students' selfassessment towards their language skills and knowledge in learning English. The following table is shown to give a summary of students' responses dealing with language skills and language aspects including grammar and vocabulary which is presented in terms of their means and ranks.

Table 2. Means and Rank of Language Skills and Language Aspects

\begin{tabular}{lll}
\hline Skills/Aspects & Means & Rank \\
\hline Listening & 2.83 & 6 \\
Speaking & 3.16 & 3 \\
Reading & 3.16 & 3 \\
Writing & 3.11 & 5 \\
Grammar & 3.30 & 2 \\
Vocabulary & 3.55 & 1 \\
\hline
\end{tabular}

As it was evidenced from the table, students seemed to feel confident of their ability in grammar and vocabulary compared to others. This result went along with $\mathrm{Al}$ Hamlan and Baniabdelrahman's (2015) study showing that vocabulary and grammar are included in two highest abilities that students felt of having high proficiency in. However, in spite of their belief of having vocabulary as their most proficient task in learning English, students were, in fact, still faced by some difficulties concerning vocabulary. This was indicated by the results gained from the interview revealing that most of the students had some problems in understanding English phrases or sentences due to their inability to cope with the meaning. Accordingly, as an attempt to cope with vocabulary problems as well as improving students' vocabulary, teachers undoubtedly need to build context while teaching English, especially in EFL context, in order to get the students think about word meaning (Harmer, 2007b). Moreover, context is necessary in teaching vocabulary since words represent multiple meanings. Meanwhile, the table above also shows that the students still need greater emphasis on listening skills. As noticed from the table, listening skill placed the least position of skills students self-assessed by the means of 2.83 . The students found it difficult to understand English questions or being asked in English. This is in line with vocabulary issue aforementioned. Through the interview session, the teachers admitted that even though the students were expected to master all language skills, listening did not have enough emphasis in TEFL practice. Coping with this problem, Cahyono and Widiati (2009) suggested that teachers are expected to help the students by activating their prior knowledge, focusing on the words that are useful for listening tasks, and telling them the purpose of their listening prior to actual listening activities.

In terms of students' linguistic needs in English, the data showed that the highest needs students thought important were learning pronunciation, being fluent in speaking, and understanding what others said. These results went along with students' motivation in learning English as revealed in the first section.Furthermore, as for curricular and extracurricular activities, it was shown that students preferred to learn English from activities that resemble daily life situations. Teachers, therefore, could insert and apply as many daily life activities as possible in teaching and learning process in the classrooms.

In section 3, it was found out that the students perceived the difficulties in learning English comes from the facilitation in language learning, lack of awareness towards learners' differences, and the feeling of frustration. This result showed a slight different emphasis from the students' answer from the interview. It can be concluded from the interview that the students tended to mention several problems related to only vocabulary and pronunciation, while in the questionnaire they seemed to highlight the role of facilitation in learning. This indicated that the students needed more facilitation to support them in learning English, forinstance, pictures that could create English learning environment in the classroom, vocabulary cards, audio/ video equipment, and so on. Meanwhile, the teachers' responses were in line with students' interview result in terms of vocabulary issue. They stated that difficulties faced by seventh graders usually came from vocabulary area.

In section 4, in terms of students' favorable learning styles, it was revealed that they preferred to learn and perform the activities in pair or in groups rather than doing 
it individually since it enables them to share their ideas and cope with the difficulties in learning easier. Dealing with this, Harmer (2007b) stated that different learners own different learning styles depending upon their characteristics. Teachers, however, as suggested by Cohen and Dornyei (2002) in Griffith (2008) should adapt classroom tasks in order to maximize the potential of individual learners with particular learning styles. Meanwhile, in terms of teaching method, the students seemed to be dependable to the teachers in learning rather than exploring the activities by themselves. This was indicated by their needs towards teachers' ability in translating the words and explaining the materials for them. Interestingly, teachers showed quite different answers regarding the issue of teaching method by putting the emphasis more on communicative approach.

The last section was functioned in finding out learners' perspectives towards effective English learning. The findings showed that the students wish to have more emphasis in learning English in terms of improvement in vocabulary, chance to communicate, and practice in the four language skills. This result was in accordance with Liton's (2012) study which suggests that attention should be paid to the increase of students' vocabulary, extra practice in language skills, and communication with classmates for the purpose of improvement in learners' learning. This finding was also supported by the students' responses in interview. They straightforwardly stated that practice was all they needed to do to be excellent in English. Meanwhile, towards this case, the teachers suggested that students need to be taught by context of language use, rather than just abstract concept. Furthermore, they also need to be exposed to new vocabularies.

\section{CONCLUSION}

This study was designed to find out the seventh graders' needs in studying English as a foreign language. It turned out from the findings that their main reasons in learning English were to travel abroad, to increase their self-confident, and to help them speaking English fluently. Meanwhile, in the terms of language skills, the students perceived that their listening and writing skills were lower than their speaking, reading, vocabulary, and grammar skills. The findings also showed that in order to pronounce English words correctly and be able to speak English fluently, the students' showed their interest by practicing them through activities that resemble daily life situations. Furthermore, according to the students' perspectives, they found the difficulties came from the insufficient facilitation in language learning and the lack of awareness towards learners' differences. However, the teachers' responses showed a slight different analysis by stating that students' difficulty revolved around vocabulary. In language learning, the students preferred to learn English in-group and they tended to be teacher-dependent, while teachers believed that communicative approach is the most suitable to be implemented in the language learning. In addition, the teachers wished to have more emphasis in learning English in terms of vocabulary improvement, chance to communicate, and practice in the four language skills.

There were some differences between the needs identified by the students and those identified by the teachers as it was described in the findings. Therefore, it can be concluded that students' views toward their needs should be taken into consideration, as there is no guarantee that the teachers can significantly represent what the students need in their learning.

Based on these findings, this study presents several recommendations in relation to the needs analysis in English learning. First, it has been witnessed that every student owns different characteristics that lead them to have different purposes and needs in language learning. An analysis towards those matters should be conducted in order to have significant learning objectives. Teachers are facilitator in learning; therefore, they are suggested to conduct needs analysis to get as closely as they can in comprehending students' view towards their needs. Second, it is recommended for further researchers who aim at investigating the same field to increase the number of participants and samples in the study to get a more comprehensive result.

\section{REFERENCES}

Al-Hamlan, S., \& Baniabdelrahman, A. A. (2015). A needs analysis approach to EFL syllabus development for second grade students in secondary education in Saudi Arabia: A descriptive analytical approach to students' needs. American International Journal of Contemporary Research, 5(1), 118-145.

Berg, B. L. (2001). Qualitative research methods for the social sciences. USA: Allyn \& Bacon.

Brown, J. D. (1995). The elements of language curriculum: A systematic approach to program development. Massachusetts: Heinle and Heinle Publishers.

Cahyono, B. Y., \& Widiati, U. (2009). The teaching of EFL listening in the Indonesian context: The state of the Art. TEFLIN Journal, 20(2).

Carter, R., \& Nunan, D. (2001). The Cambridge guide to teaching English to speakers of other languages. Cambridge: Cambridge University Press.

Dornyei, Z. (2005). Motivational strategies in the language classroom. Cambridge: Cambridge University Press.

Fraenkel, J. R., \& et. al. (2012). How to design and evaluate research in education: Eight edition. New York: McGraw-Hill.

Griffiths, C. (2008). Lessons from good language learners. Cambridge: Cambridge University Press.

Harmer, J. (2007b). How to teach English. China: Pearson Education Limited.

Hutchinson, T., \& Waters, A. (1987). English for Specific Purposes: A learning-centered approach. Cambridge: Cambridge University Press. 
Kaboody, M. A. (2013). Second language motivation: The role of teachers in learner's motivation. Journal of Academic and Applied Studies , 45-54.

Liton, H. A. (2012). Developing EFL teaching and learning practices in Saudi colleges: A review. International Journal of Instruction, 5(2), 129-152.

Lowe, I. (2009). Needs analysis. Lecture Notes and Summary, 1-11.

Malik, R. S., \& Hamied, F. A. (2016). Research methods: A guide for first time researchers. Bandung: UPI Press.

Martin, B. (2005). Assessing students' perceived language needs in a needs analysis. 9th Proceeding of the 9th Conference of Pan Pacific Association of Applied Linguistics, 26-43.

Nation, I. S., \& Macalister, J. (2010). Language curriculum design. New York: Routledge.

Richards, J. C. (2001). Currulum development in language teaching . New York: Cambridge University Press.

Songhori, M. H. (2008). Introduction to needs analysis. English for Specific Purposes World (4), 1-25.

Soruc, A. (2012). The role of needs analysis in language program renewal process. Mevlana International Journal of Education (MIJE), 2(1), 36-47.

Watanabe, Y. (2006). A needs analysis for a Japanese high school EFL general education curriculum. Second Language Studies, 25 (1), 83-163. 